\title{
Predicting Consumer Intention to Adopt Online Grocery Shopping: A Comparative Study between Millennials in Thailand and Indonesia
}

\author{
Athapol Ruangkanjanases * \\ Chulalongkorn Business School, Chulalongkorn University, Thailand \\ athapol@cbs.chula.ac.th \\ Pattanaporn Sirisrisakulchai \\ Chulalongkorn Business School, Chulalongkorn University, Thailand \\ pattanaporn.fah@gmail.com \\ Natalia \\ BINUS Business School, Bina Nusantara University, Indonesia \\ National Taiwan University of Science and Technology, Taiwan \\ natalia@binus.edu \\ Bachtiar H. Simamora \\ BINUS Business School, Bina Nusantara University, Indonesia \\ bsimamora@binus.edu
}

\begin{abstract}
This study focuses on the behavioral intention to purchase groceries from virtual supermarkets by millennials. This research also aims to compare the influencing factors between Thai and Indonesian consumers. The study applies the Technology Acceptance Model (TAM), which is widely accepted to study technology adoption. The hypotheses are constructed to test four independent variables, which are social influence, perceived usefulness, perceived ease of use, and trust and security, and their effects on consumers' attitudes and intention to purchase grocery online. This study uses a survey to collect data from 400 respondents, 200 who are Thai millennials and 200 who are Indonesian millennials. The results show that perceived usefulness and trust and security are significant factors affecting both Thai and Indonesian consumers' intention to adopt online grocery shopping. In addition, perceived ease of use has an effect on the intention to adopt online grocery shopping only for Thai millennials while social influence has an effect only on Indonesian millennials' intention to adopt.
\end{abstract}

Keywords: Purchase Intention, Online Grocery Shopping, Technology Acceptance Model, Millennial

\section{INTRODUCTION}

Nowadays, technology has shifted the retail industry. The business of consumer goods and the retail industry have to face the challenging issue of shoppers' expectations from supermarkets and retail stores. Retail stores need to adapt to meet 
changing consumers' expectations by providing more convenient options, such as online shopping and mobile payment acceptance etc.

Online grocery shopping is a service from a brick-and-mortar supermarket or grocery store that allows consumers to order online, or an e-commerce service that includes grocery items. Online grocery shopping is facilitated by delivery service. Online grocery shopping is in the mainstream for online activities worldwide, and the e-retail sales accounted for 10.2 percent of all retail sales globally and it is expected to grow to 17.5 percent in 2021 according to Statista [1].

Online grocery shopping is an e-commerce activity that facilitates online shoppers because an online channel is the most convenient channel allowing them to purchase anytime, anywhere via their smartphones and devices.

Previous studies have shown that there are some factors in the technology acceptance model (TAM) affecting the purchase intentions of online buyers towards online groceries.

This study will focus on the intentions to purchase online grocery shopping of Thai and Indonesian consumers in the range of the millennial generation.

The authors found this topic interesting as many reports lately indicated that online grocery has the potential to grow rapidly in Asia, especially in Indonesia and Thailand. A few years ago, the number one online grocery shopping company in Southeast Asia, which is founded in Indonesia, HappyFresh [2] , expanded its business to Thailand. Market feedback has been satisfactory for the company. On the other hand, this study could be beneficial for Thai supermarket stores, such as Gourmet Market- a Thai premium supermarket, which sees the growth of grocery trends in Asia, and sees an opportunity to expand its business online to a successful online grocery market like Indonesia.

Even though, the TAM model has been studied purchase intentions towards online grocery shopping, there has been no comparison study that investigates consumers intentions to adopt online grocery shopping between Thai and Indonesian consumers before.

\section{LITERATURE REVIEW}

Howe and Strauss [3] defined millennials as individuals born between 1982 and 2004 who reached adulthood around the turn of the $21^{\text {st }}$ century. There is a wide range of characteristics within this generational cohort, and the issue of millennials and technology is essentially related to the research topic.

Millennials have grown up in an online and social network society. They are familiar with computers, the internet, and graphical user interfaces (GUI) [4]. This familiarity makes them adjust to new programs, operating systems, and devices to perform computer-based tasks easier and faster than previous generations. A survey of millennials in 2015 [5] described that millennials do not tolerate waiting in lines. People in this generation expect speed and ease of use. A study by Howe and Strauss reported that millennials tend to adopt new technology and expect technology to simply work. Furthermore, millennials are a sociable generation. They socialize online as well as in real life. They connect and share habits of virtual sociability. Marketer Jeff Fromm [6] presented that millennials seek the opinions of others when it comes to shopping issues. 
His research stated that millennials tend to make decisions to purchase after they have discussed it with a few other people that they trust. Female millennials particularly prefer to shop as a group.

According to IGD, the International Grocery Research Organization, it was revealed that Asia's grocery segment has continually and rapidly been developing. In 2019, the pace of the grocery segment is expected to change the future of online shopping, said Nick Miles, Head of the Asia-Pacific Region at IGD [5]. Ultimate convenience is becoming a key trend that is shaping Asia's grocery market and influences industry strategy. Lifestyles of buyers across Asia are becoming more demanding, people are demanding to be able to procure products anywhere, at any time. Technology is transforming the grocery industry in Asia. Suppliers need to understand customer's preferences and to be open to adopting technology in order to improve their business.

In the Asia-Pacific region, Indonesia is one of the fastest growing markets for online retail, followed by India and China [6]. Indonesia is a booming market for online retails. The trend of buying groceries online is becoming more popular among urbanized people in Indonesia. Asia Outlook Magazine [7] referred to a report from Research and Markets which presented that the online retail market in Indonesia has been the biggest in the region. Indonesian consumers turn to shop on e-commerce platforms, such as Tokopedia or a grocery application called TaniHub, as online grocery shopping can offer them quality products at cheaper prices. This has caused Indonesia to become the biggest booming market for online retails in Asia.

Recently, Tetra Pak Thailand, the local unit of the world's leading food processing and packaging solutions company, released a report which focused on the rise of online grocery shopping in Thailand. The online grocery sector in Thailand is predicted to grow five-fold by 2030 [8].

With recent digital retail development, online access is constantly improving. Mobile phones and smartphones play a significant role in online communities; the majority of online shopping orders are made through smartphones and tablet devices. The internet shopping trend in Thailand is in line with the global trend for online groceries shopping [9]. One in five Thai consumers now buys products online on a daily basis, especially in the food and groceries category. Online food and groceries shopping demands in Thailand have increased rapidly and are continually arising.

The model of this study is inspired by the technology acceptance model (TAM) as this model is used widely to explain behaviors of online shoppers. The TAM theory consists of significant factors as following: Perceived Usefulness (PU), Perceived Ease of Use (PEOU), and External variables such as Social Influence (SI). Various research [10], [11] has applied TAM because of its understandability and simplicity. The determinants that commonly resulted as the significant factors are perceived usefulness and perceived ease of use.

Also, the study is inspired by a proposed framework of Pauzi et al. [12] which consists of five variables: social influence, facilitating conditions, hedonic motivations, perceived risk and trust. Kian et al. [13] uses a model that comprises of perceived usefulness, perceived ease of use, visibility, and social influence.

As online grocery shopping involves online payment methods and delivery services. Researchers are interested in extending a scope of investigation which 
includes these additional services as a new variable. Thus, researchers selected significant factors affecting consumers' intention in previous studies and added Trust and Security (TS) as a new variable to the framework for this study.

To simplify a model framework, the authors have regrouped the independent variables from the theory of technology acceptance model (TAM) and the models from previous studies as mentioned above, and proposed a model framework to use in this study. The proposed model consists of the four following factors: Trust and Security, Perceived Usefulness, Perceived Ease of Use, and Social Influence, which have an effect on consumers' intentions to purchase online groceries.

\section{HYPOTHESES DEVELOPMENT AND RESEARCH MODEL}

The conceptual model was developed based on the study of the acceptance of online grocery shopping model conducted by Kurnia and Chien [14]. The developed model framework will be used in the study of predicting consumers intention to use online grocery shopping consists of these following factors:

\subsection{Trust and Security}

Shadkam et al. [15] reported that trust and risk perception is a key element driving consumers to use the system, especially payments concerns. Li et al. [16] also stated that trust is a more vital factor for online shopping than offline shopping because customers realize there is a greater risk in virtual stores due to their incapability of visiting a physical store.

This variable focuses on consumer concerns about the method of payment included in electronic retailers and the delivery services, which is the most important feature driving the adoption of online grocery shopping. Therefore, this study hypothesizes that:

Hypothesis 1a (H1A) Trust and security has a significant effect on the intention to purchase online groceries by Thai millennial consumers.

Hypothesis 1b (H1B) Trust and security has a significant effect on the intention to purchase online groceries by Indonesian millennial consumers.

\subsection{Perceived Usefulness}

Perceived usefulness [17] strongly affects the intention to purchase online. Monsuwe and Ruyter [18] found that "usefulness" referred to customers' recognition that utilizing the Internet as a shopping medium gives a better shopping experience and that recognition impacts buyers' attitude towards online shopping and their intention to shop online. Piyanath \& Suthawan [19] presented that perceived usefulness is essential for mass market innovation acknowledgment, which relies on upon shoppers' assumptions about how innovation can enhance and facilitate their lives. Furthermore, perceived usefulness is also a foundation influencing consumers to buy products. Therefore, this study hypothesizes that:

Hypothesis 2a (H2A) Perceived usefulness has a significant effect on the intention to purchase online groceries by Thai millennial consumers. 
Hypothesis 2b (H2B) Perceived usefulness has a significant effect on the intention to purchase online groceries by Thai millennial consumers.

\subsection{Perceived Ease of Use}

According to TAM, perceived ease of use is one of the major factors that impacts on the intention to use new technology or services. Sulistiyaningsih et al. [20] translated perceived ease of use as a level where a customer sees the technology as something simple to use. Davis [17] indicated that potential clients assume that a specific innovation is helpful; they may likewise trust that the innovation is not difficult to utilize. Perceived ease of use in this context is the level of an individual perception on the processes of the system or online platform. Therefore, this study hypothesizes that:

Hypothesis 3a (H3A) Perceived ease of use has a significant effect on the intention to purchase online groceries by Thai millennial consumers.

Hypothesis 3b (H3B) Perceived ease of use has a significant effect on the intention to purchase online groceries by Indonesia millennial consumers.

\subsection{Social Influence}

Because humans are social animals, social influence has been considered as one of factors influencing intentions to use online grocery shopping. Social influence can be defined as an individual perception for accepting a new system on influence or suggestion from the person's importance concerning the individual [21]. Furthermore, the previous study from Jalilvanda et al. [22] reported that online consumer reviews play two roles in social influence, which are informative and suggestive. Therefore, this study hypothesizes that:

Hypothesis 4a (H4A) Social influence has a significant effect on the intention to purchase online groceries by Thai millennial consumers.

Hypothesis 4b (H4B) Social influence has a significant effect on the intention to purchase online groceries by Indonesia millennial consumers.

Based on the developed conceptual framework, the hypotheses of the research are created as follows:

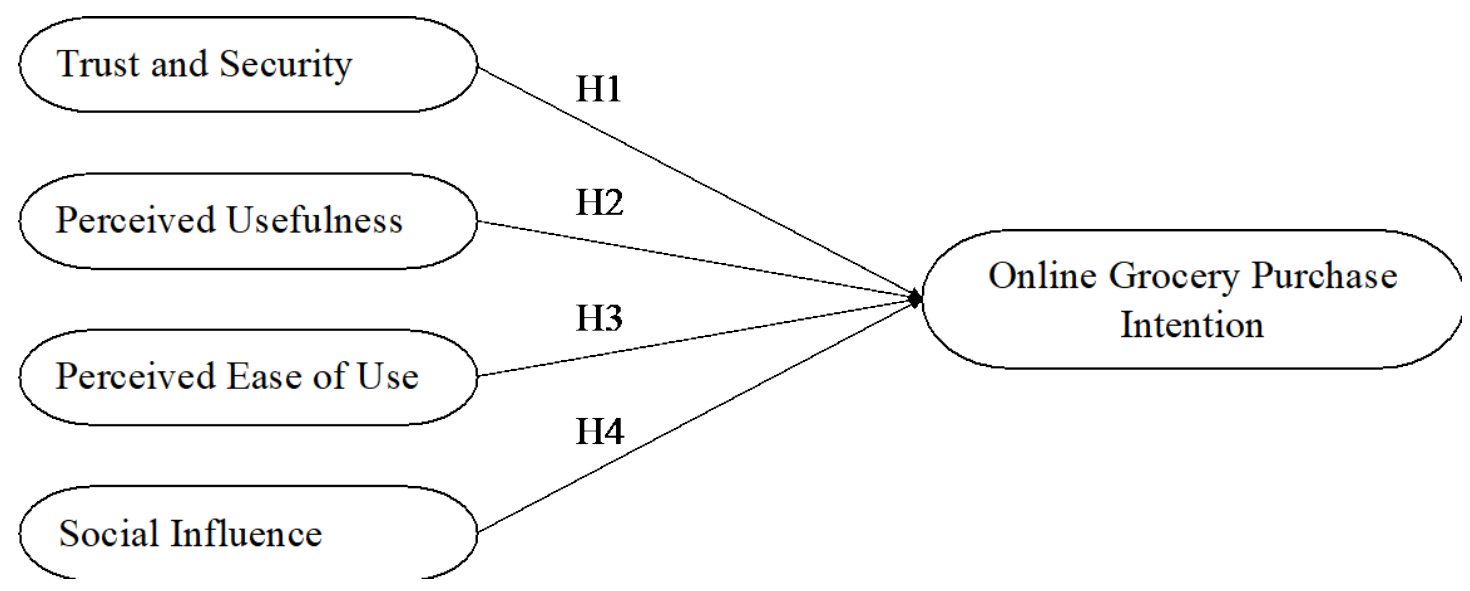

Figure 1. Conceptual model 


\section{METHODOLOGY}

\subsection{Sample size and Data Collection}

The participants' population consists of Thai and Indonesian people who have the potential to shop online for groceries, which accounted for around 86 million people [23]. By using a 95\% confidence level with a sampling error of 5\% based on Yamane's formula [24], the sample size of the respondents was 400. Data was collected via a questionnaire from August to December 2018. From a total of 400 completed and returned questionnaires, 200 were from Thai millennials and 200 from Indonesian millennials.

All respondents had experiences in online shopping. Demographic profiles of respondents are shown in Table 1.

Descriptive Statistics

A total 400 respondents collected from online surveys are used as the sample group for data analysis in this study. The data is comprised of 200 responses from Thai millennials and another 200 responses from Indonesian millennials. Table 3 shows that the majority of Thai respondents are female while the majority of Indonesian respondents are male.

Table 1. Demographic Profiles

\begin{tabular}{lcccc}
\hline & \multicolumn{2}{c}{ Thai respondents } & \multicolumn{2}{c}{ Indonesian respondents } \\
\hline $\begin{array}{l}\text { Demographic profile } \\
\text { Gender }\end{array}$ & Number & Percentage & Number & Percentage \\
Male & 50 & 25 & 105 & 52.5 \\
Female & 150 & 75 & 95 & 47.5 \\
\hline
\end{tabular}

\subsection{Research Instrument and Variable Measurement}

An online questionnaire is used as an instrument to collect primary data. A screening question was set as the first question in the questionnaire to confirm that each respondent has experiences in online shopping. The questionnaire consists of 21 questions used to measure four independent variables, and five questions were used to measure a dependent variable. Besides demographic information, all items are measured on a five-point Likert scale ranging from 1 (strongly disagree) to 5 (strongly agree). A sample of the questionnaire is in the Appendix.

\subsection{Reliability}

Reliability analysis is conducted to measure the internal consistency of a set of items as a group. Table 2 shows that the Composite Reliability values are all above 0.7. Therefore, the question items used are reliable. 
Table 2. Reliability Analysis

\begin{tabular}{lcc}
\hline Reliability Analysis & Thai respondents & Indonesian respondents \\
\hline Variable & Composite Reliability & Composite Reliability \\
Trust and Security & 0.822 & 0.856 \\
Perceived Usefulness & 0.791 & 0.803 \\
Perceived Ease of Use & 0.835 & 0.817 \\
Social Influence & 0.703 & 0.756 \\
Behavioral Intention & 0.714 & 0.796
\end{tabular}

\subsection{Validity}

Factor analysis with varimax rotation is applied to test the validity of the model constructs. Factor loading of 0.50 is used as a cut-off point based on Hair et al. [25] The results in table 2 present the existence of 4 factors with eigenvalues greater than 1.0 and all items have a factor loading of more than 0.50 .

Table 3. Factor Analysis

\begin{tabular}{lcccc}
\hline \multicolumn{1}{c}{ Construct } & $\begin{array}{c}\text { No. of } \\
\text { items }\end{array}$ & Factor Loading & Eigenvalue & $\begin{array}{c}\text { Percentage of } \\
\text { Variance }\end{array}$ \\
\hline $\begin{array}{l}\text { Trust and Security } \\
\begin{array}{l}\text { Perceived } \\
\text { Usefulness }\end{array}\end{array}$ & 5 & $0.465-0.794$ & 4.690 & 18.039 \\
$\begin{array}{l}\text { Perceived Ease of } \\
\text { Use }\end{array}$ & 4 & $0.752-0.758$ & 3.042 & 11.701 \\
$\begin{array}{l}\text { Social Influence } \\
\text { Behavioral Intention }\end{array}$ & 4 & $0.528-0.789$ & 2.903 & 11.167 \\
\hline
\end{tabular}

\section{DATA ANALYSIS}

Statistical Package for Social Sciences (SPSS) is used to analyze primary data collected from online questionnaires in this study.

\subsection{T-test Analysis}

The results from table 4 indicate that the mean scores of Thai respondents are significantly different from the mean scores of Indonesian respondents in terms of these following factors: Perceived Ease of Use (PE), Trust and Services (TS), and Behavioral Intention to adopt online grocery shopping services, as its p-value is less than 0.05 . Hence, this research topic should be continued to study the significant factors influencing consumers' behavioral intention to use online grocery shopping. 
Table 4. Independent Sample T-test

\begin{tabular}{|c|c|c|c|c|c|c|c|c|c|}
\hline & \multicolumn{3}{|c|}{$\begin{array}{l}\text { Levene's Test for } \\
\text { Equality of } \\
\text { Variances }\end{array}$} & \multicolumn{4}{|c|}{ T-test for Equality of Means } & \multicolumn{2}{|c|}{$\begin{array}{l}95 \% \text { Confidence } \\
\text { Interval of the } \\
\text { Difference }\end{array}$} \\
\hline & $\mathrm{F}$ & Sig. & $\mathrm{t}$ & df & $\begin{array}{l}\text { Sig. (2- } \\
\text { tailed) }\end{array}$ & $\begin{array}{c}\text { Mean } \\
\text { Difference }\end{array}$ & $\begin{array}{l}\text { Std. Error } \\
\text { Difference }\end{array}$ & Lower & Upper \\
\hline \multirow[t]{2}{*}{ SI } & 0.06 & 0.806 & -0.525 & 398 & 0.600 & -0.032 & 0.062 & -0.154 & 0.089 \\
\hline & & & -0.525 & 397.971 & 0.600 & -0.032 & 0.062 & -0.154 & 0.089 \\
\hline \multirow[t]{2}{*}{ PU } & 0.471 & 0.493 & 1.095 & 398 & 0.274 & 0.058 & 0.053 & -0.046 & 0.163 \\
\hline & & & 1.095 & 397.724 & 0.274 & 0.058 & 0.053 & -0.046 & 0.163 \\
\hline \multirow[t]{2}{*}{ PE } & 0.049 & 0.825 & 2.605 & 398 & 0.010 & 0.149 & 0.057 & 0.037 & 0.261 \\
\hline & & & 2.605 & 396.589 & 0.010 & 0.149 & 0.057 & 0.037 & 0.261 \\
\hline \multirow[t]{2}{*}{ TS } & 1.549 & 0.214 & 7.724 & 398 & 0.000 & 0.353 & 0.046 & 0.263 & 0.442 \\
\hline & & & 7.724 & 389.437 & 0.000 & 0.353 & 0.046 & 0.263 & 0.442 \\
\hline \multirow[t]{2}{*}{ BI } & 2.267 & 0.133 & 3.697 & 398 & 0.000 & 0.224 & 0.061 & 0.105 & 0.343 \\
\hline & & & 3.697 & 397.996 & 0.000 & 0.224 & 0.061 & 0.105 & 0.343 \\
\hline
\end{tabular}

\subsection{Correlation Analysis}

Correlation analysis is a method of statistical evaluation used to measure the strength and direction of a linear relationship between independent and dependent variables in a study.

The correlation analysis is conducted to review Pearson's correlation. The linear correlation coefficient is used to rate and measure a linear relationship between two variables.

Table 5 presents the correlation of variables for Thai respondents. All independent variables have a significant relationship with the dependent variable that is behavioral Intention (BI), which ranged from $r=0.288$ to $r=0.496$. Referring to table 4 , perceived usefulness (PU) has the strongest correlation with the behavioral intention to use online grocery shopping $(\mathrm{BI})$ among Thai respondents $(\mathrm{r}=0.496)$. On the other hand, trust and security (TS) has the lowest impact on BI for Thai respondents $(r=0.288)$.

Table 5. Correlation among five variables of Thai respondents

\begin{tabular}{lccccc}
\hline Variables & TS & PU & PE & SI & BI \\
\hline Trust and Security & 1 & 0.192 & 0.216 & 0.126 & 0.288 \\
Perceived Usefulness & & 1 & 0.555 & 0.299 & 0.496 \\
Perceived Ease of Use & & & 1 & 0.319 & 0.424 \\
Social Influence & & & & 1 & 0.304 \\
Behavioral Intention & & & & & 1
\end{tabular}

Notes: $\mathrm{TS}=$ Trust and Security, $\mathrm{PU}=$ Perceived Usefulness, $\mathrm{PE}=$ Perceived Ease of use, $\mathrm{SI}=$ Social Influence, and BI=Behavior Intentions.

Significant level at 0.05 
According to table 6, the correlation of variables for Indonesian respondents that have a significant relationship ranged from $r=0.435$ to $r=0.610$. The variable with the strongest correlation value is perceived usefulness (PU) with $r=0.610$, and social influence is the lowest value, $r=0.435$.

Table 6. Correlation among five variables of Indonesian respondents

\begin{tabular}{lccccc} 
Variables & TS & PU & PE & SI & BI \\
\hline Trust and Security & 1 & 0.394 & 0.340 & 0.178 & 0.601 \\
Perceived Usefulness & & 1 & 0.583 & 0.430 & 0.610 \\
Perceived Ease of Use & & & 1 & 0.358 & 0.491 \\
Social Influence & & & & 1 & 0.435 \\
Behavioral Intention & & & & & 1
\end{tabular}

Notes: TS=Trust and Security, $\mathrm{PU}=$ Perceived Usefulness, $\mathrm{PE}=$ Perceived Ease of use, $\mathrm{SI}=$ Social Influence, and $\mathrm{BI}=$ Behavior Intentions.

Significant level at 0.05

Nevertheless, some Pearson's correlation values between independent variables are above 0.5 which may lead to multicollinearity, such as PU and PE for both Thai and Indonesian respondents at $\mathrm{r} 0.555$ and $\mathrm{r} 0.583$, respectively. Thus, collinearity diagnostic tests are necessary to be performed in the following step.

\subsection{Collinearity Diagnostics}

Collinearity diagnostic tests are to check independent variables to see when two variables have near perfect linear combinations of one another. According to O'Brien [26], a variable that has the tolerance value below 0.2 or the VIF above 5 possesses a multi-collinearity problem.

Table 7 presents the collinearity statistics of four variables for Thai respondents. The tolerance value of all variables ranges from 0.656 to 0.944 , which could be interpreted that there is no multicollinearity issue.

Table 7. Collinearity diagnose for Thai respondents

\begin{tabular}{lcc}
\hline Variables & \multicolumn{2}{c}{ Collinearity statistics } \\
\hline & Tolerance & VIF \\
Perceived Usefulness & 0.671 & 1.491 \\
Trust and Security & 0.944 & 1.060 \\
Perceived Ease of Use & 0.656 & 1.525 \\
Social Influence & 0.875 & 1.143 \\
\hline
\end{tabular}

Furthermore, the tolerance value of all variables for Indonesian respondents ranges from 0.631 to 0.844 as shown in Table 8 . Therefore, the multicollinearity problem does not exist. 
Table 8. Collinearity diagnose for Indonesian respondents

\begin{tabular}{lcc}
\hline Variables & \multicolumn{2}{c}{ Collinearity statistics } \\
\hline & Tolerance & VIF \\
Perceived Usefulness & 0.711 & 1.406 \\
Trust and Security & 0.844 & 1.184 \\
Social Influence & 0.815 & 1.227 \\
Perceived Ease of Use & 0.631 & 1.584 \\
\hline
\end{tabular}

\subsection{Stepwise Multiple Regression Analysis and Hypotheses Test}

Multiple regression analysis is used to measure a linear relationship of four independent variables in the conceptual model and a dependent variable, which is online grocery purchase intention, and to scrutinize the impacts of independent variables on a dependent variable in the hypotheses.

According to table 9, three variables appear to have a significant impact on the intention to use online grocery shopping for Thai respondents in the millennial generation, which are perceived usefulness $(\beta=0.335, \mathrm{p}=0.000)$, trust and security $(\beta=0.173, \mathrm{p}=0.005)$, and perceived ease of use $(\beta=0.159, \mathrm{p}=0.030)$. The adjusted $\mathrm{R}^{2}$ is at 0.309 , which means the three variables could explain $30.9 \%$ of the variance of the dependent variable (intention to use online grocery shopping).

According to table 10, three variables appear to have a significant impact to the intention to use online grocery shopping for Indonesian respondents in the millennial generation, which are perceived usefulness $(\beta=0.354, \mathrm{p}=0.000)$, trust and security $(\beta=0.424, \mathrm{p}=0.000)$, and social influence $(\beta=0.208, \mathrm{p}=0.000)$. The adjusted $\mathrm{R}^{2}$ is at 0.555 , which means the three variables could be explained $55.5 \%$ of the variance of dependent variable (intention to use online grocery shopping).

The result from stepwise multiple regression analysis presents that the hypotheses $\mathrm{H} 1 \mathrm{~A}, \mathrm{H} 1 \mathrm{~B}, \mathrm{H} 2 \mathrm{~A}, \mathrm{H} 2 \mathrm{~B}, \mathrm{H} 3 \mathrm{~A}$, and $\mathrm{H} 4 \mathrm{~B}$ are supported. The result of the multiple regression analysis does not support $\mathrm{H} 4 \mathrm{~A}$ and $\mathrm{H} 3 \mathrm{~B}$.

In conclusion, the factors influencing the online grocery purchase intentions of Thai respondents in the millennial generation are shown in figure 2 and factors influencing the online grocery purchase intentions of Indonesian respondents in the millennial generation are shown in figure 3.

Table 9. Stepwise Multiple Regression Analysis of Thai Respondents

\begin{tabular}{clcccccccc}
\hline & \multicolumn{1}{c}{ Variables } & $\mathrm{B}$ & $\beta$ & $\mathrm{t}$ & $\mathrm{Sig}$. & $\mathrm{R}$ & $\mathrm{R}^{2}$ & $\begin{array}{c}\text { Adj. } \\
\mathrm{R}^{2}\end{array}$ & $\begin{array}{c}\text { Overall } \\
\mathrm{F}\end{array}$ \\
\hline Criterion: & $\begin{array}{l}\text { Behavioral } \\
\text { Intention }\end{array}$ & & & & & 0.569 & 0.323 & 0.309 & 23.283 \\
Predictor: & $\begin{array}{l}\text { Perceived } \\
\text { Usefulness }\end{array}$ & 0.313 & 0.335 & 4.656 & 0.000 & & & & \\
& $\begin{array}{l}\text { Trust and } \\
\text { Security } \\
\text { Perceived }\end{array}$ & 0.219 & 0.173 & 2.849 & 0.005 & & & & \\
& 0.144 & 0.159 & 2.181 & 0.030 & & & & \\
\hline
\end{tabular}


Ease of Use

Table 10. Stepwise Multiple Regression Analysis of Indonesian respondents

\begin{tabular}{|c|c|c|c|c|c|c|c|c|c|}
\hline & Variables & B & $\beta$ & $\mathrm{t}$ & Sig. & $\mathrm{R}$ & $\mathrm{R}^{2}$ & $\begin{array}{l}\text { Adj. } \\
\mathrm{R}^{2}\end{array}$ & $\begin{array}{c}\text { Overall } \\
\text { F }\end{array}$ \\
\hline Criterion: & $\begin{array}{l}\text { Behavioral } \\
\text { Intention }\end{array}$ & & & & & 0.749 & 0.561 & 0.555 & 83.584 \\
\hline \multirow[t]{3}{*}{ Predictor: } & $\begin{array}{l}\text { Perceived } \\
\text { Usefulness }\end{array}$ & 0.363 & 0.354 & 6.306 & 0.000 & & & & \\
\hline & $\begin{array}{l}\text { Trust and } \\
\text { Security }\end{array}$ & 0.490 & 0.424 & 8.239 & 0.000 & & & & \\
\hline & $\begin{array}{l}\text { Social } \\
\text { Influence }\end{array}$ & 0.190 & 0.208 & 3.963 & 0.000 & & & & \\
\hline
\end{tabular}

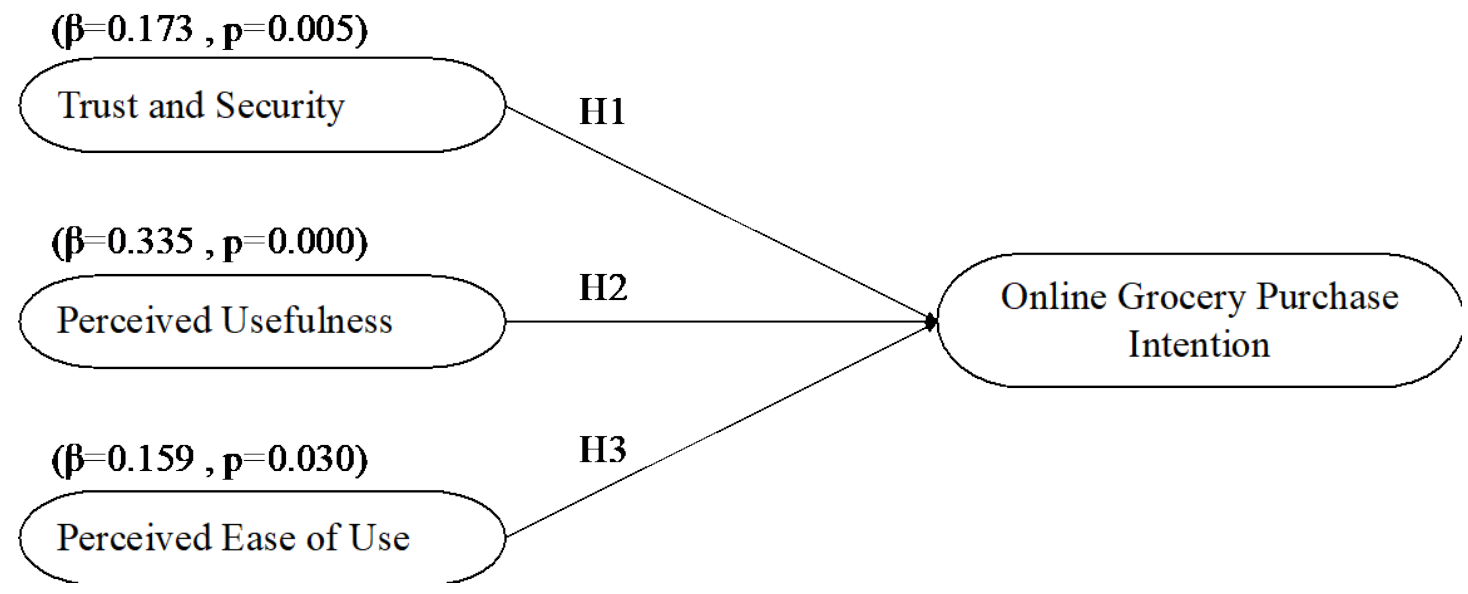

Figure 2. Multiple Regression Analysis of Thai Respondents

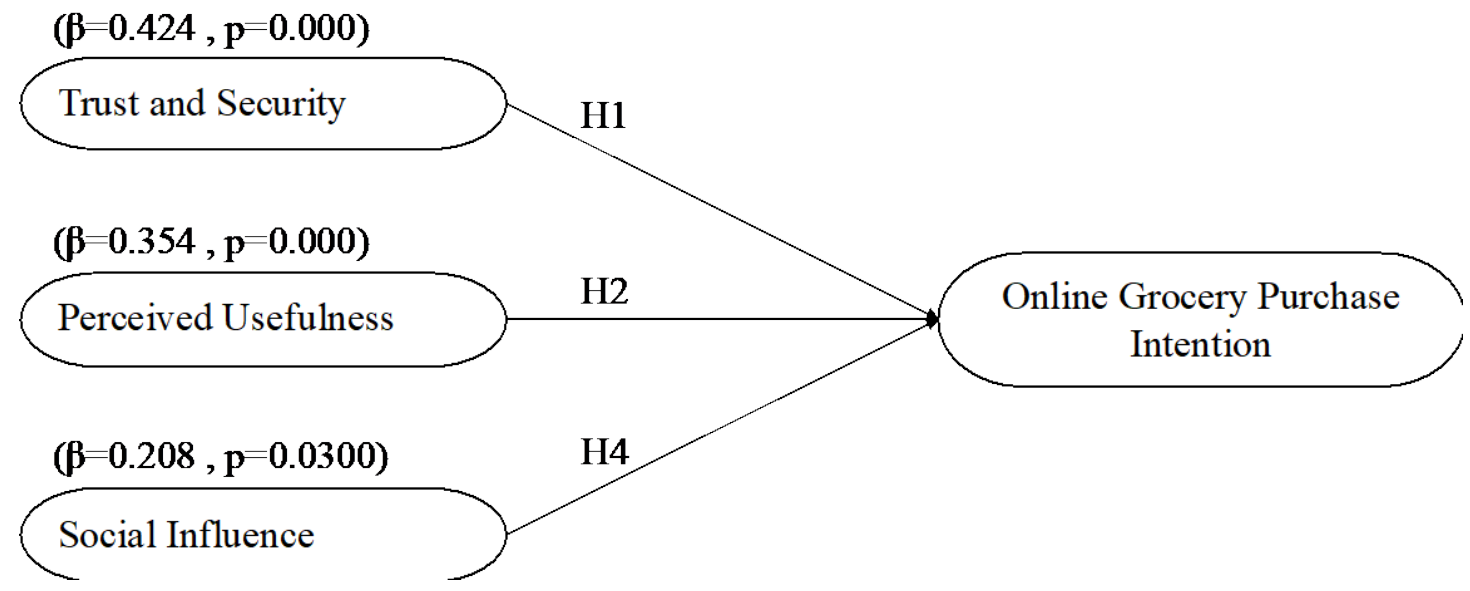

Figure 3. Multiple Regression Analysis of Indonesian Respondents

\section{CONCLUSION}


The connection between Thailand and Indonesia has been built over a long history. The close relationship between the two countries is augmented by its geographical, cultural, religious, and historical proximities. Thailand has a strong trading relation with Indonesia since the early centuries; the connection has become even closer after the foundation of the Association of Southeast Asian Nations (ASEAN) that aims to accelerate economic growth, promote intergovernmental cooperation, including to facilitate political, educational and sociocultural integration among its members in Asia.

The study has identified the significant factors that influence the intention to use online grocery shopping of millennial generations for both Thai and Indonesian respondents, which are trust and security (TS) and perceived usefulness (PU). According to the results, it can be interpreted that both groups of consumers highly expect secured methods of payment and good delivery services from online supermarkets. Furthermore, both Thai and Indonesian shoppers are more likely to use online grocery services when they have needs and when they see that online grocery shopping is convenient for them. The first two factors can be interpreted that trust and security and perceived usefulness are fundamental causes of using online shopping for groceries.

On the other hand, the research has also shown that Thai respondents in the millennial generation tend to use online grocery shopping when its system and processes are easy to use, since perceived ease of use (PE) presents as the least significant factor influencing behavioral intention to use online grocery shopping for Thai millennials. While perceived ease of use (PE) is a significant variable for Thai respondents, it does not affect the intention to purchase groceries online for Indonesian respondents. The study has found that another factor to impact Indonesian respondents is social influence. It can be interpreted that Indonesian respondents in the younger millennial generation tend to rely on recommendations from current online shoppers or suggestions from people that they are familiar with. Hence, social influence is a significant factor that urges Indonesian respondents to use online grocery shopping. The result of the study supports a previous study by Howe and Strauss [4] that millennials prefer new simplified technology and they also rely on direct experiences from surrounding people before making a purchase.

As the Asia Outlook reported the number of smartphone users in Indonesia has exponentially risen in recent times, it could be interpreted that Indonesian consumers represent online shoppers at an immature stage. They tend to be open to new online services and platforms, and they are also willing to learn new processes of e-commerce systems. Therefore, perceived ease of use is not a main concern to adopt online grocery services. Besides, collectivism is a term used to describe how people co-habit in the Asia region, according to Hofstede. Social influence becomes the key to drive Indonesian consumers to use online grocery shopping as they are likely to obtain information from real users that they know before making a purchase decision to avoid any unpleasant issues.

While Thai consumers have been familiar with smartphones and online shopping, Thai consumers always share their purchase experiences in both online and offline channels. It is common for them to shop online nowadays. Therefore, Thai consumers tend not to rely on social influence to make online purchases. Additionally, one of wellknown Thai personality traits is the concept of 'Sabai-Sabai' (to be easygoing). Thai 
consumers tend to emphasize convenience to spending less time on one activity. Thus, perceived ease of use is likely to be a factor affecting their purchase intentions.

The result of this study supports previous studies and research that the major factors driving consumers to accept services are necessity and having a reliable system. Previous studies [13], [15] and the outcome of this research emphasize that perceived usefulness, a key factor in the TAM, is a fundamental requirement to drive shoppers to use new online services such as online grocery systems. Moreover, trust and security is also one of the vital drivers to encourage buyers to accept online grocery shopping. [11], [17] Online shopping expect reliable and secured methods of payment and order accuracy from the online grocery services. Social influence is a new factor that has appeared in recent studies [15], [17] in which people tend to rely on direct experiences from current users' online and offline feedback. Furthermore, online channel shoppers purchase their groceries because it is convenient. Hence, these four significant factors are base needs that an online supermarket business should consider in order to improve their business and respond to customer's needs.

Additionally, this study provides pragmatic recommendations for retail business owners and business developers to improve their marketing strategies and service solutions. Apart from the secure payment methods, in order to attract Thai online shoppers in the Millennials, online shopping platforms need to be as simple as possible. Retail websites or applications should facilitate users from the initial click through to payment for delivery. In addition, online shopping services will attract more buyer's attention if business providers support free shipping and provide real-time shipments tracking for buyers. S. N. Ahmad \& M. Callow [27] supported that a free shipping service works better in comparison with a discount for low-priced goods.

On the other hand, Indonesian segment demands not only the secured payment, they also need trusted endorsements from people. Business providers should add features of product reviews and present positive feedback towards their shopping platforms from real users and trendsetters. N. Singh et al. [28] found that the positive attitude of users towards online platform helps improve behavioral intentions. They also used Social Influence to conduct a study of the relationship between perceived consumer satisfaction and recommendation to use a new technology.

The main goal of the current study is to determine significant factors influencing Thai and Indonesian millennials to purchase groceries online, and to compare both similar and different factors which have an impact on people from the two nations. In addition, the present study can be investigated further in order to consider more influences related to different cultures or other aspects. Since the Technology Acceptance Model (TAM) is used as a fundamental theory to form a research model in this study, researchers could contribute a further model framework with more complexity in a future research. For instance, the Theory of Planned Behavior (TPB) could be interesting to be studied in this topic to prove whether consumers' behavior can be planned according to Fishbein \& Ajzen [29]. Moreover, future researchers may merge these correlated theories such as TAM, TPB, and Theory of Reasoned Action (TRA) to study consumers' intentional behavior in other aspects for a better understanding of consumer' behaviors. The future research framework can be developed with more relevant factors to acquire more precise results. 


\section{APPENDIX}

Rate these following questions from $1=$ strongly disagree to $5=$ strongly agree.

\section{Trust and Security}

1. I am concerned with the accuracy of ordered items.

2. I am concerned with the privacy of my information provided when using Online Grocery Shopping.

3. I am concerned with the payment security aspects of Online Grocery Shopping.

4. I am concerned with exchange policy when receiving unsatisfied products.

5. I am concerned with the quality of the products delivered when ordering from Online Grocery Shopping.

6. My trust and security concerns will affect my decision to adopt Online Groceries Shopping.

7. I am concerned with the punctuality of the delivery time of Online Grocery Shopping.

8. Using Online Grocery Shopping can overcome the obstacles for physically disabled people.

\section{Perceived Usefulness}

1. Using Online Grocery Shopping can increase my productivity.

2. Using Online Grocery Shopping can make my grocery shopping easier.

3. Using Online Grocery Shopping can save me a lot of time.

4. Using Online Grocery Shopping is convenient for my grocery shopping.

5. Using Online Grocery Shopping can enhance my effectiveness in purchasing groceries.

\section{Perceived Ease of Use}

1. My interaction with the processes of Online Grocery Shopping is clear and understandable.

2. It is easy for me to follow the procedures when ordering groceries online.

3. It is easy to become skillful at using Online Grocery Shopping.

4. Online Grocery Shopping is easy-to-use.

\section{Social Influence}

1. I will adopt Online Grocery Shopping if my friends/relatives use it.

2. I will use Online Grocery Shopping if the service is widely used by people in my community.

3. I will adopt Online Grocery Shopping if my boss uses it.

4. I tend to use Online Grocery Shopping if there are reviews from current online shoppers.

\section{Behavioral Intention}

1. Whenever possible, I intend to use Online Grocery Shopping to purchase groceries.

2. I intend to use Online Grocery Shopping when the price is competitive.

3. I intend to use Online Grocery Shopping when there is free home delivery. 
4. I intend to use Online Grocery Shopping when the service becomes widely available.

5. Using Online Grocery Shopping can improve my efficiency in purchasing groceries.

\section{REFERENCES}

[1] K. Striapunina, Indonesia: retail e-commerce revenue forecast from 2017 to 2024[Online]. Available: https://www.statista.com/statistics/280925/b2c-ecommerce-sales-in-Indonesia/

[2] WhatIsTechTarget.com, 2019. M. Rouse, Millennials (Generation Y) [Online]. Available: https://whatis.techtarget.com/definition/millennials-millennialgeneration

[3] N. Howe \& W. Strauss. (2003), Five Characteristics of Millennials [Online]. Available: https://michiganscouting.org/wp-content/uploads/2017/11/FiveCharacteristics-of-Millennials.pdf

[4] G. McGovern, Millennial Attitude. (2017). Chapter 8 from Transform: A Rebel's Guide for Digital Transformation [Online]. Available: https://medium.com/ (a) gerrymcgovern/millennial-attitude-846fec2a4aba

[5] A. Crisp (2018), IGD reveals top trends set to shape Asian grocery in 2019 [Online]. Available: https://www.igd.com/articles/article-viewer/t/igd-revealstop-trends-set-to-shape-asian-grocery-in-2019/i/20627

[6] EMarketer. (2018). Retail e-commerce sales worldwide from 2014 to 2023 [Online]. Available: https://www.statista.com/statistics/379046/worldwide- retaile-commerce-sales/

[7] AsiaOutlook. (2018). Indonesia: A Booming Market for Online Shopping [Online]. Available: https://www.asiaoutlookmag.com/news/Indonesia-abooming-market-for-online-shopping

[8] The Nation. (2018). Tetra Pak report focuses on rise and challenges of Thai online grocery sector [Online]. Available: http://www.nationmultimedia.com/detail/breakingnews/30351661

[9] The Nation. (2014). Thais follow global trend towards more online shopping. Available: http://www.nationmultimedia.com/business/Thais-follow-globaltrend-towards-more-online-shop-30250393.html

[10] I. Hong \& H. Cho, "The impact of consumer trust on attitudinal loyalty and purchase intentions in B2C e-marketplaces: Intermediary trust vs seller trust," International Journal of Information Management, Vol. 31, No 5, Pages 469479, 2011.

[11] M. Saleem, M.M. Khan, M.E. Ahmed, S.A. Neha Shah, and S.R. Surti, "Online grocery shopping and consumer perception: a case of karachi market in Pakistan," Journal of Internet and e-Business Studies, Vol. 2018 (2018), Article ID 931248, Pages 1-13, 2018.

[12] S.F.F. Pauzi, A.C. Thoo, L.C. Tan, F.M. Muraram, and N.A. Talib, "Factors influencing consumers intention for online grocery shopping - a proposed framework," IOP Conference Series: Materials Science and Engineering, Vol. 215, No. 1, 1-12, 2013. Available: http://iopscience.iop.org/article/10.1088/1757899X/215/1/012013/ meta

[13] T. P. Kian, A. C. W. Loong, \& S. W. L. Fong, "Customer purchase intention on online grocery shopping," International Journal of Academic Research in Business and Social Sciences, Vol. 8, No, 12, 1579-1595, 2018. 
[14] S. Kurnia, \& A.W.J. Chien, "The acceptance of online grocery shopping," in $16^{\text {th }}$ Bled eCommerce Conference, Bled, Slovenia, 2003.

[15] M. Shadkam, S. Kavianpour, S. Honarbakhsh, \& L.W. Hooi. "Antecedents of consumers' intention to shop online," Australian Journal of Basic and Applied Sciences, Vol. 7, No. 13, 190-197, 2013.

[16] J. Li, \& H. Ohlsson, "Online grocery shopping: the key factors influencing consumers' purchase intention - A study based on consumers in Sweden," Thesis, Jönköping International Business School, Jönköping University, Sweden, 2017.

[17] F.D. Davis, "Perceived usefulness, perceived ease of use \& user acceptance of information technology," MIS Quarterly, Vol. 13, No. 3 , 319 - 340, 1989.

[18] T.P. Monsuwé, B.G.C. Dellaert, K. de Ruyter. (2004). "What drives consumers to shop online? A literature review," International Journal of Service Industry Management [Online],Vol.15No.1, Available: https://doi.org/10.1108/09564230410523358

[19] P. Maneechot, and S. Chirapanda, "Factors affecting behavioral intention to purchase low-cost airline e-ticket in Thailand," International Journal of Business and Economics, 41-57, 2013.

[20] M. Sulistiyaningsih, J. J. Tambotoh, \& A. R. Tanaamah, “Technology acceptance model and online learning media: an empirical study of online learning application in a private Indonesian university," Journal of Theoretical and Applied Information Technology, Vol. 69, No.1, pp. 136-144, 2014.

[21] V. Venkatesh, \& M. G. Morris, "Why don't men ever stop to ask for directions? gender, social influence, and their role in technology acceptance and usage behavior," MIS Quarterly, Vol.24, No.1, 115-139, 2000.

[22] M. R. Jalilvanda, S.S. Esfahani, and N. Samiei, "Electronic word-of-mouth: Challenges and opportunities," Procedia Computer Science, No.3, pp. 42-46, 2011.

[23] Euromonitor \& dbs group research. (2018, Nov. 24). Modern grocery retail (MGR) penetration forecast for ASEAN-5 in 2021, by country [Online]. Available: https://www.statista.com/statistics/857417/asean-5-modern-groceryretail-penetration-forecast-by-country/

[24] T. Yamane, Statistics: An Introductory Analysis, 2nd Ed., New York: Harper and Row. 1967.

[25] J. F. Hair, W. C. Black, \& B. J. Babin, Anderson, R.E., Multivariate data analysis: A global perspective. New Jersey, Pearson Education. 2010.

[26] R.M. O'brien, "A caution regarding rules of thumb for variance inflation factors," Quality \& Quantity, Vol. 41, No. 5, pp.673-690, 2007.

[27] S. N. Ahmad, \& M. Callow, "Free shipping" or "dollar off"? the moderating effects of list price and e-shopping experience on consumer preference for online discount," International Journal of Electronic Commerce Studies, Vol. 9, No. 1, 55-70, 2018.

[28] N. Singh, N. Sinha, \& F. J. Liébana-Cabanillas, "Determining factors in the adoption and recommendation of mobile wallet services in India: analysis of the effect of innovativeness, stress to use and social influence," International Journal of Information Management, Vol. 50, pp. 191-205, 2020.

[29] M. Fishbein, \& I. Ajzen, Predicting and changing behavior: the reasoned action approach. New York, Psychology Press (Taylor \& Francis). 2010. 